\title{
Effects of the glyphosate-resistance gene and herbicides on soybean: Field trials monitoring biological nitrogen fixation and yield
}

\author{
Mariangela Hungria $^{\mathrm{a}, *}$, Iêda Carvalho Mendes ${ }^{\mathrm{b}}$, André Shigueyoshi Nakatani ${ }^{\mathrm{a}, \mathrm{c}}$, \\ Fábio Bueno dos Reis-Junior ${ }^{\mathrm{b}}$, José Zucca Morais ${ }^{\mathrm{a}}$, \\ Maria Cristina Neves de Oliveira ${ }^{a}$, Marcelo Ferreira Fernandes ${ }^{d}$ \\ a Embrapa Soja, C.P. 231, 86001-970 Londrina, PR, Brazil \\ b Embrapa Cerrados, C.P. 08223, 73301-970 Planaltina, DF, Brazil \\ ${ }^{\mathrm{c}}$ Postdoctoral Research Fellow from CNPq, Brasília, DF, Brazil \\ d Embrapa Tabuleiros Costeiros, C.P. 44, 49025-040 Aracaju, SE, Brazil
}

\section{A R T I C L E I N F O}

\section{Article history:}

Received 29 July 2013

Received in revised form 20 December 2013

Accepted 23 December 2013

\section{Keywords:}

Biological nitrogen fixation

Glycine max

Glyphosate

Roundup Ready ${ }^{\circledR}$ soybean

Transgenic soybean

\begin{abstract}
A B S T R A C T
The commercial use of glyphosate-resistant (also known as Roundup Ready ${ }^{\circledR}$, GR or RR) soybean was initiated in 1996 in the United States. This genetically engineered crop now occupies 75.4 million ha worldwide, 20.6 million of which are in Brazil where it occupies $86 \%$ of the total area cropped with the legume. Biological nitrogen fixation (BNF) is critical for economic sustainability of soybean in Brazil; therefore, to investigate the effects of the RR gene-using pairs of nearly isogenic cultivars-and herbicides on BNF, we conducted an extensive series of field experiments for three cropping seasons. The experiments were set up at six sites with five treatments, three pairs of nearly isogenic cultivars, and six replicates. The treatments consisted of: (T1) RR soybean + glyphosate; (T2) RR soybean + conventional herbicides; (T3) conventional parental soybean + conventional herbicides; (T4) RR soybean + hand weed control; and (T5) conventional parental soybean + hand weed control. Parameters of nodulation, plant biomass production, total $\mathrm{N}$ and ureide- $\mathrm{N}$ were evaluated at the V4 and $\mathrm{R} 2$ stages of growth, and grain yield and total $\mathrm{N}$ in grains were evaluated at crop maturity. Data were analyzed by ANOVA, analyses of contrasts, and multivariate analyses considering a pool of six variables, denominated as symbiotic efficiency (SyEf). The comparison of the pairs of non-transgenic and RR soybean cultivars showed that the transgenic trait negatively affected some BNF variables, but over a three-year period these effects had no significant impact on soybean grain yield. No consistent differences between glyphosate and conventional herbicide application were observed on BNF-associated parameters. When compared to conventional soybean and conventional herbicides, weed-management strategy with RR soybean and glyphosate did not affect symbiotic efficiency. In addition, at three sites, grain yields increased in the treatments with glyphosate and RR soybean over the three cropping seasons. The results from the multivariate analyses indicate that BNF and yield parameters were more affected by location, cropping season and cultivar than by the transgene, herbicides, or weed-management strategy. Despite the lack of effects of the transgene on yield in the three-year period, longer-term effects on BNF and N accumulation should be monitored.
\end{abstract}

(c) 2014 Elsevier B.V. All rights reserved.

\footnotetext{
* Corresponding author. Tel.: +55 43 33716206; fax: +55 4333716100 .

E-mail addresses: mariangela.hungria@embrapa.br,

hungria@cnpq.br, biotecnologia.solo@hotmail.com, hungria@pq.cnpq.br (M. Hungria), ieda.mendes@embrapa.br (I.C. Mendes),

andrenakatani@yahoo.com.br (A.S. Nakatani), fabio.reis@embrapa.br

(F.B. dos Reis-Junior), jose.morais@embrapa.br (J.Z. Morais),

mcristina.oliveira@embrapa.br (M.C.N. de Oliveira),

marcelo.fernandes@embrapa.br (M.F. Fernandes).
}

\section{Introduction}

The commercial use of glyphosate-resistant soybean [Glycine $\max \left(\right.$ L.) Merr.], also called Roundup Ready ${ }^{\circledR}-\mathrm{RR}$ started in 1996 in the United States; and today this crop occupies about 75.4 million ha worldwide (ISAAA, 2012). The release of commercial RR soybean cultivars opened new opportunities for weed control by enabling: (i) reduction and replacement of pre-emergence herbicides; (ii) early seeding and no-tillage cropping; and (iii) less crop injury (Carpenter and Gianessi, 2001). In Brazil, RR soybean was released in 2003 and rapidly adopted by farmers. In the 2010/2011 growing season it was grown on 20.6 million ha, representing $86 \%$ 
of the total area cultivated with this crop in Brazil (ISAAA, 2012); in other major producing countries, such as the United States and Argentina, the area planted with RR soybean is close to $100 \%$.

Glyphosate [N-(phosphomethyl) glycine, marketed as Roundup $^{\circledR}$ by Monsanto Company, St. Louis, MO] is a broadspectrum (controls both broad-leaf and grass weeds), non-selective herbicide, with a short mean active life in the soil environment (Franz et al., 1997). Its mechanism of action is based on the inhibition of the synthesis of aromatic amino acids (phenylalanine, tyrosine and tryptophan), by blocking the shikimic acid pathway present in plants and microorganisms, but absent from animals; hence, it shows low mammalian toxicity (Jaworski, 1972; Fisher et al., 1986). The basis of resistance to glyphosate in soybean is the insertion of a 5-enolpiruvylshikimic acid-3-phosphate synthase (EPSPS) gene derived from Agrobacterium strain CP4, which is insensitive to this herbicide, allowing the functional expression of the shikimic acid pathway in its presence (Padgette et al., 1995; Zablotowicz and Reddy, 2004).

The release of genetically engineered soybean cultivars has raised the question of whether the symbiotic nitrogen fixation process would be affected or not. The use of herbicides may affect biological nitrogen fixation (BNF) directly through effects on the bacteria (Jaworski, 1972), indirectly through effects on the legume host (Johnson, 1971), and also in the symbiosis (Gonzalez et al., 1996). Therefore, it is important that the biotechnological advances that have enabled the generation of genetically modified soybeans are also accompanied by rigorous studies of environmental safety. This is necessary not only to ensure the occurrence of minimal impacts on the environment, but also that gains already obtained from research, such as the contribution of high rates of nitrogen fixation, are not negatively affected. The importance of BNF in Brazil is highlighted when we consider that, in 2013, it was estimated that the application of inoculants containing $\mathrm{N}_{2}$-fixing bacteria, to the 27 million ha cropped with soybean, produces an annual savings of approximately US $\$ 10$ billion due to the non-use of nitrogen fertilizers, without taking into account the benefits on the environment (Hungria et al., 2013).

Adverse effects of glyphosate on Bradyrhizobium japonicum have been related to the accumulation of shikimic acid and hydroxibenzoic acids, causing growth inhibition, and sensitivity varies among strains (Moorman et al., 1992; Hernandez et al., 1999; Drouin et al., 2010). At high concentration of glyphosate Bradyrhizobium death can occur (Fisher et al., 1986). In evaluations of the symbiosis soybean-Bradyrhizobium, although some deleterious effects of glyphosate on the nodulation and/or $\mathrm{N}_{2}$ fixation processes have been reported (Reddy et al., 2000; King et al., 2001; Reddy and Zablotowicz, 2003; Zablotowicz and Reddy, 2004; Dvoranen et al., 2008; Bohm et al., 2009; Kremer and Means, 2009), grain-yield reductions have not been demonstrated. The magnitude of the effects on the symbiosis, including nodulation and plant-related parameters vary with glyphosate dose, salt, time of application, soybean cultivar, geographical location and environmental conditions, and are accentuated under water stress and in sandy soils (Zablotowicz and Reddy, 2004).

It is possible that, in the long term, the reductions of nodule mass and BNF rates by RR soybeans can lead to increased scavenging of mineral $\mathrm{N}$. The uptake of more $\mathrm{N}$ from the soil will result in depletion of organic matter reserves and lower soil fertility. The situation is especially critical in sandy soils with limited $\mathrm{N}$ availability (Zablotowicz and Reddy, 2004; Bohm et al., 2009).

Considering the potential for reduced BNF in the RR soybean under field conditions, in this work we report the results of an extensive series of field experiments carried out between 2003 and 2006 in the most prominent soybean-producing regions of Brazil. Our objective was to evaluate the effects of the RR transgene, glyphosate and weed-management strategy on BNF and yield parameters, by using pairs of nearly isogenic soybean cultivars.

\section{Materials and methods}

\subsection{Geographic location, general description of the field sites, treatments and logistics}

The experiments were set up in the 2003/2004, 2004/2005 and 2005/2006 growing seasons at six sites in Brazil: Passo Fundo (Rio Grande do Sul State); Ponta Grossa (Paraná State; except in 2003/2004); Londrina (Paraná State); Uberaba (Minas Gerais State); Planaltina (Federal District); and Luiz Eduardo Magalhães (Bahia State). Details on location, climate and soil classification are given in Table 1. At each site soil samples were collected before the establishment of the experiment at a depth of $0-20 \mathrm{~cm}$ in five different points to form a composite sample. At each point 10 sub-samples were taken. These sub-samples were homogenized in large plastic bags, transported to the laboratory and sieved through a 4-mm sieve. Soil analyses were performed as described before (Hungria et al., 2006b) and the results are shown in Table 1. Table 1 also shows data on soil organic carbon (SOC), which under tropical conditions gives a good reference in terms of the soil capacity to supply N.

In each region, the trials were conducted in a completely randomized block design, with 5 treatments $\times 3$ pairs of cultivars, with 6 replicates, in a total of 90 plots. The five treatments consisted of: (T1) RR soybean + glyphosate; (T2) RR soybean + conventional herbicides; (T3) conventional parental soybean + conventional herbicides; (T4) RR soybean + hand weeding; (T5) conventional parental soybean + hand weeding, as the control.

For T1, Roundup Transorb ${ }^{\circledR}$ (glyphosate, Monsanto), was applied at a dose of $2 \mathrm{Lha}^{-1}$ in 200 $\mathrm{L}$ of water, 20-30 days after emergence, whereas $0.5 \mathrm{~L} \mathrm{ha}^{-1}$ of Select ${ }^{\circledR} 240$ (Clethodim ${ }^{\circledR}$, Milenia, Londrina), mixed with mineral oil at $0.5 \%$ of the volume (to kill narrow-leaf weeds), and Classic ${ }^{\circledR}$ (chlorimuron-ethyl, DuPont, Wilmington, DE) at $80 \mathrm{~g} \mathrm{ha}^{-1}$ (to kill broad-leaf weeds) were used for T2 and T3. Three pairs of cultivars, each consisting of the parental non-transgenic cultivar (from Embrapa Soja's breeding program) and its respective nearly transgenic counterpart (from a Embrapa Soja-Monsanto partnership) were cropped at each site, in a total of 15 treatments per site. In the three growing seasons, the pairs of soybean cultivars tested in Ponta Grossa and Londrina were Conquista/ValiosaRR(Cultivar $1=$ C1); BRS133/BRS245RR (Cultivar 2=C2); and Embrapa 59/BRS244RR (Cultivar 3=C3). These same cutivars were tested in Passo Fundo, except that in 2004/2005 and 2005/2006, when Conquista/ValiosaRR were replaced by Embrapa58/BRS242RR. In 2003/2004, the soybean cultivars tested in areas of the central region (Uberaba, Planaltina, Luiz Eduardo Magalhães) were Conquista/ValiosaRR (Cultivar 1 =C1); BRS133/BRS245RR (Cultivar 2=C2); and Jataí/SilvâniaRR (Cultivar 3=C3). In 2004/2005 and 2005/2006, the same cultivars were tested, except for BRS133/BRS245RR, which were replaced by Celeste/BalizaRR. Genealogy and maturity groups of parental conventional types were as follows: Conquista MG/BR 46 (Lo76-4484 × Numbaíra, G.8.1); BRS 133 (FT Abyara $\times$ BR 83146, G.7.3); Embrapa 59 (FT Abyara $\times$ BR83-147, G.7.3); Embrapa 58 (Paraná $\times$ BR83-143, G.7.4); BRS/GO Jataí [Embrapa 313 (Anhanguera) $\times$ BR92-31910 (Cristalina CARDF-30*3 $\times$ FT Estrela), G.8.9]; BRS Celeste (Bossier $\times$ BR 1T, G.8.1); they all have determinate type of growth. The replacements were made when cultivars showed relatively poor performance, being replaced by better adapted, newly released genotypes.

All areas were managed under a no-tillage system and cropped with soybean in the summer. In the winter, the areas were sown 


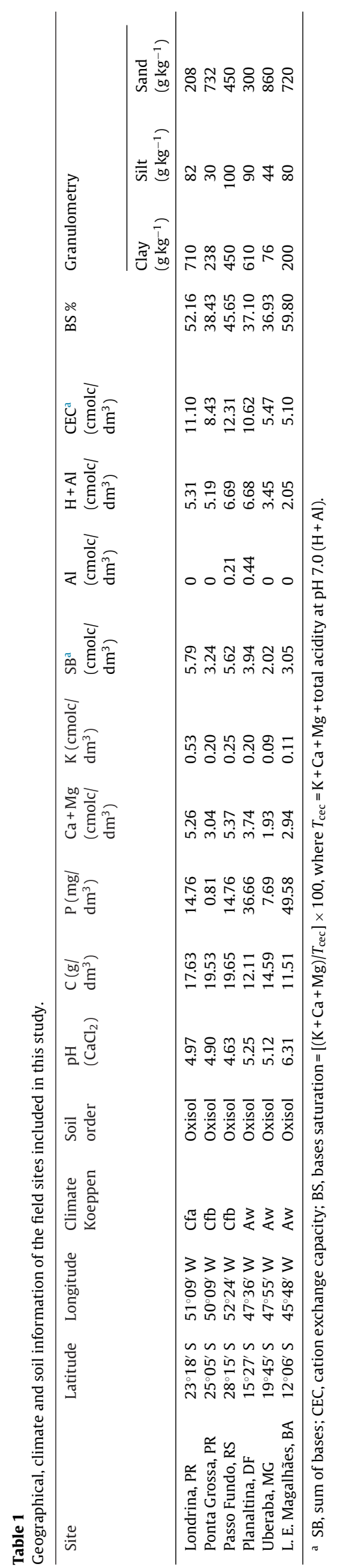

with black oat (Avena strigosa L.) or wheat (Triticum aestivum L.) in the south region (Passo Fundo, Ponta Grossa and Londrina), and pearl-millet (Pennisetum americanum) in the central region (Uberaba, Planaltina and Luiz Eduardo Magalhães).

Immediately prior to planting, the soybean seeds were treated with a peat-based inoculant produced at Embrapa Soja and containing a 1:1 mixture of broth cultures of B. elkanii strain SEMIA 587 and B. diazoefficiens strain CPAC 7 (=SEMIA 5080), at a concentration of $10^{9}$ cells $\mathrm{g}^{-1}$ of peat and supplied to provide 1.2 million cells seed $^{-1}$. Inoculation was done by using a peat slurry prepared with $200 \mathrm{~g}$ of inoculant in $300 \mathrm{~mL}$ of a $10 \%(\mathrm{w} / \mathrm{v})$ sucrose adhesive solution per $50 \mathrm{~kg}$ of seeds. Sowing was done manually, with 25-30 seeds per meter of row. The experimental plots were $5.0 \mathrm{~m} \times 6.0 \mathrm{~m}$, with rows spaced at $1.0 \mathrm{~m}$. The plots consisted of 10 rows each, $50 \mathrm{~cm}$ apart.

\subsection{Harvests, parameters evaluated and laboratory analyses}

At the V4 and R2 stages of growth (Fehr et al., 1971), ten soybean plants per plot were randomly chosen and carefully excavated for determinations of shoot dry weight (SDW), nodule number (NN), and nodule dry weight (NDW). The root systems were rinsed with tap water and the nodules were detached, dried at $65^{\circ} \mathrm{C}$ for $72 \mathrm{~h}$, weighed and counted. SDW was determined after drying in a forced-air dryer at $65^{\circ} \mathrm{C}$, also for approximately $72 \mathrm{~h}$. Total shoot-N concentration (TSNC) and shoot-N concentration (SNC) were determined by the Kjeldahl method and total shoot nitrogen content (TSNC) was determined as the product of SNC and SDW. Leaf petioles were dried at $65^{\circ} \mathrm{C}$, ground (20 mesh) and analyzed for both $\mathrm{N}$-ureide (\% and total N-ureide-TNU) (Herridge and Peoples, 1990) and nitrate contents, to determine the percentage of petiole $\mathrm{N}$ as $\mathrm{N}$-ureides (\%NU), as an indicator of the relative contribution of BNF to total N nutrition (Herridge and Peoples, 1990; Hungria et al., 2006b).

At harvest, pods were taken from the plants from two central 5.0-m long rows in each plot, and seeds removed, cleaned, weighed and soybean grain yields (SGYs) expressed in $\mathrm{kg} \mathrm{ha}^{-1}$ after adjusting moisture content to $13 \%$. Total grain-N content (TGN, $\left.\mathrm{kg} \mathrm{Nha}^{-1}\right)$ and the concentration of grain $\mathrm{N}(\% \mathrm{GN})$ were determined by the Kjeldahl method. In the present study, the following variables related to BNF were evaluated: NDW V4 (mg plant $\left.{ }^{-1}\right)$, NDW R2 (mg plant ${ }^{-1}$ ), SNC R2 (mg N g plant ${ }^{-1}$ ), TSNC R2 (mg N plant ${ }^{-1}$ ), \%NU R2 (\%), and TNU R2 (mg N-ureide plant ${ }^{-1}$ ). Some data of NN (nodules plant $\left.{ }^{-1}\right)$, SDW $\left(\mathrm{g} \mathrm{plant}^{-1}\right)$ and SNC $\left(\mathrm{g} \mathrm{kg}^{-1}\right)$ from either V4 or R2 stages were lost due to adverse weather; therefore, these variables were not considered in the data analysis.

\subsection{Statistical analyses}

Prior to the analysis of variance (ANOVA), data were tested for normality of variables and uniformity of variance (SAS Institute, 1999). After that, data were submitted to mean contrast analysis, considering all three seasons of data, to compare the effects of the transgenic trait (Contrast 1 ), the type of herbicide in transgenic cultivars (Contrast 2), and weed-management strategy (Contrast 3) on soybean yield, \% Grain N (\%GN), and BNF variables, as follows: Contrast 1, transgenic vs. non-transgenic (only conventional herbicide and hand-weeding $)[(\mu \mathrm{T} 2 \mathrm{C} 1+\mu \mathrm{T} 2 \mathrm{C} 2+$ $\mu \mathrm{T} 2 \mathrm{C} 3+\mu \mathrm{T} 4 \mathrm{C} 1+\mu \mathrm{T} 4 \mathrm{C} 2+\mu \mathrm{T} 4 \mathrm{C} 3) / 6]-[(\mu \mathrm{T} 3 \mathrm{C} 1+\mu \mathrm{T} 3 \mathrm{C} 2+\mu \mathrm{T} 3 \mathrm{C} 3+$ $\mu \mathrm{T} 5 \mathrm{C} 1+\mu \mathrm{T} 5 \mathrm{C} 2+\mu \mathrm{T} 5 \mathrm{C} 3) / 6] ; \quad$ Contrast 2 , transgenic with glyphosate vs. transgenic with conventional herbicide $[(\mu \mathrm{T} 1 \mathrm{C} 1+\mu \mathrm{T} 1 \mathrm{C} 2+\mu \mathrm{T} 1 \mathrm{C} 3) / 3]-[(\mu \mathrm{T} 2 \mathrm{C} 1+\mu \mathrm{T} 2 \mathrm{C} 2+\mu \mathrm{T} 2 \mathrm{C} 3) / 3]$; and Contrast 3 , transgenic with glyphosate vs. nontransgenic with conventional herbicide $[(\mu \mathrm{T} 1 \mathrm{C} 1+\mu \mathrm{T} 1 \mathrm{C} 2+$ $\mu \mathrm{T} 1 \mathrm{C} 3) / 3]-[(\mu \mathrm{T} 3 \mathrm{C} 1+\mu \mathrm{T} 3 \mathrm{C} 2+\mu \mathrm{T} 3 \mathrm{C} 3) / 3]$, where T1, T2, T3, T4, T5 represent the treatments and $\mathrm{C} 1, \mathrm{C} 2, \mathrm{C} 3$ represent the three pairs of cultivars used at each site. Means $(\mu)$ were estimated across 
Table 2

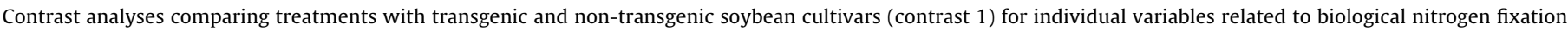
across three crop seasons.

\begin{tabular}{|c|c|c|c|c|c|c|c|}
\hline \multirow{3}{*}{ Site } & \multirow{3}{*}{ Contrast } & \multicolumn{6}{|c|}{ Soybean Developmental Stage } \\
\hline & & \multirow{2}{*}{$\begin{array}{l}\text { V4 } \\
\text { NDW }\end{array}$} & \multicolumn{5}{|l|}{ R2 } \\
\hline & & & NDW & SNC & TSNC & $\% \mathrm{NU}$ & TNU \\
\hline \multirow[t]{3}{*}{ Passo Fundo } & Transgenic & 0.66 & 1.19 & 39.60 & 2848.51 & 72.80 & 2103.26 \\
\hline & Non-transgenic & 0.77 & 1.46 & 39.29 & 3297.16 & 72.73 & 2428.10 \\
\hline & $p$ & ns & ${ }^{* *}$ & ns & ns & ns & ns \\
\hline \multirow[t]{3}{*}{ Ponta Grossa ${ }^{a}$} & Transgenic & 0.77 & 1.46 & 46.38 & 9591.89 & 77.65 & 7350.75 \\
\hline & Non-transgenic & 0.90 & 1.85 & 45.65 & $10,492.02$ & 79.03 & 8169.61 \\
\hline & $p$ & & & ns & ns & & ns \\
\hline \multirow[t]{3}{*}{ Londrina } & Transgenic & 0.26 & 0.77 & 42.47 & 4768.73 & 74.10 & 3511.84 \\
\hline & Non-transgenic & 0.29 & 0.86 & 42.69 & 5280.21 & 77.91 & 4110.06 \\
\hline & $p$ & ns & & ns & & & \\
\hline \multirow[t]{3}{*}{ Uberaba } & Transgenic & 1.58 & 2.74 & 45.14 & 5283.34 & 80.67 & 4306.48 \\
\hline & Non-transgenic & 1.52 & 2.76 & 44.52 & 5391.86 & 80.53 & 4362.82 \\
\hline & $p$ & ns & ns & ns & ns & ns & ns \\
\hline \multirow[t]{3}{*}{ Planaltina } & Transgenic & 1.47 & 2.15 & 47.31 & 4671.98 & 77.83 & 3669.58 \\
\hline & Non-transgenic & 1.52 & 2.46 & 47.94 & 5449.75 & 84.94 & 4632.10 \\
\hline & $p$ & ns & & ns & ns & & \\
\hline \multirow[t]{3}{*}{ Luiz Eduardo Magalhães } & Transgenic & 1.09 & 3.16 & 44.49 & 4802.00 & 78.74 & 3824.46 \\
\hline & Non-transgenic & 1.19 & 3.36 & 45.27 & 5462.77 & 80.10 & 4391.47 \\
\hline & $p$ & ns & ns & ns & & ns & \\
\hline
\end{tabular}

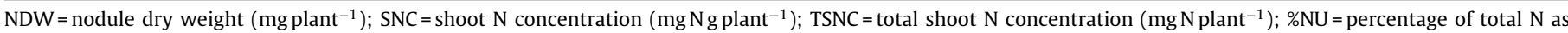
$\mathrm{N}$-ureide; $\mathrm{TNU}=$ total $\mathrm{N}$ as ureide- $\mathrm{N}$ ( mg ureide- $\mathrm{N}$ plant $^{-1}$ ).

a This site was evaluated only during seasons 2004/2005 and 2005/2006.

${ }^{*} p<0.05$.

** $p<0.005$.

the three sampling seasons and contrast analyses performed separately for each site, as cultivars varied between regions. Contrast significance was assessed by the Student $t$ test $(p \leq 0.05)$.

In addition, we used a multivariate analysis to evaluate the effects of the transgenic trait, type of herbicide and weed-control strategy on symbiotic efficiency (SyEf), described by the simultaneous analysis of the six pooled variables (NDW V4, NDW R2, SNC R2, TSNC R2, \%NU R2 and TNU R2). For this, the data were analyzed using multivariate ordination "non-metric multidimensional scaling" (NMS) (Sokal, 1979), with Sorensen distances. Prior to the analysis, data were standardized by totals within each variable in order to eliminate the differences in the variable units. The ordination was performed in the autopilot mode, using the "slow and thorough" option in the program PC-ORD v. 6.0 (McCune and Mefford, 2011). The number of dimensions to be interpreted was selected considering the criteria of stress and stability of the graphical solutions.

Variations in the SyEf among samples were characterized by Pearson correlation coefficients between the sample scores on the NMS axes 1 and 2 and the values of the six attributes that described the SyEf.

A multiresponse permutation procedure (MRPP, Mielke and Berry, 2000) was employed to test the hypothesis of no effect of transgenic trait, herbicide and weed control strategy on SyEf, using the same three contrasts described for the univariate analysis. In all cases, Sorensen distance measures were used. Values of $p$ associated with test statistics $(T)$ were determined by numerical integration of the Pearson type III distribution. All multivariate tests were performed using the statistical program PC-ORD v. 6.0 (McCune and Mefford, 2011).

For each tested contrast, SyEf was modeled using sums of squares multivariate regression tree (SS-MRT) models (De'ath, 2002), with site, season, cultivar, and contrast treated as categorical explanatory variables, in order to verify the contribution of the different factors on the explained SyEf data variability. A series of 20-10-fold cross-validations (Breiman et al., 1984) were run in this study to choose the most frequently occurring (modal) tree size with a minimum error rate (De'ath and Fabricius, 2000). The final tree size was chosen using the 1-SE (standard error) rule (Breiman et al., 1984), which results in a smaller tree than that suggested by the minimum cross-validated-error rate (at most 1-SE). A library of S-Plus functions for tree routines (RPART: recursive partitioning), developed by T. Therneau (unpublished data) was used for all SS-MRT models. S-Plus (version 4.0) statistical software (Mathsoft, 1999) was used for these analyses.

\section{Results}

\subsection{Effect of the transgenic trait and glyphosate on biological nitrogen fixation (BNF) parameters - univariate analyses}

The transgenic trait impaired several BNF parameters (at least one of the six variables evaluated per site) at all sites except for Uberaba (Table 2). NDW R2 was the attribute most negatively affected by the transgenic trait, with reductions ranging from 10 to $21 \%$ at four of the six sites. The lower NDW values at R2 observed at Ponta Grossa, Londrina and Planaltina, but not at Passo Fundo, were congruent with the decrease in the \% $\mathrm{NU}$ in the transgenic cultivars (Table 2).

Although the treatments with glyphosate had overall higher means for the BNF parameters, no consistent differences between the herbicides (glyphosate or conventional) were observed (Contrast 2, Table 3). Significant increments due to the glyphosate were dependent on the region and the variable under analysis, and were observed only at R2 for TSNC (from 12 to $49 \%$ in three regions), \%NU (about 4\% in two regions) and TNU (17-22\% in three regions). In contrast, conventional herbicide had higher \%NU at Passo Fundo and Uberaba, but with low relative increments, ranging from 1 to $3 \%$. At Planaltina, no differences in BNF variables were detected between the herbicides (Table 3 ). 
Table 3

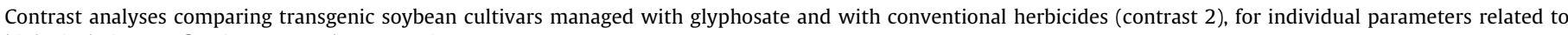
biological nitrogen fixation, across three cropping seasons.

\begin{tabular}{|c|c|c|c|c|c|c|c|}
\hline \multirow{3}{*}{ Site } & \multirow{3}{*}{ Contrast } & \multicolumn{6}{|c|}{ Soybean Developmental Stage } \\
\hline & & \multirow{2}{*}{$\begin{array}{l}\text { V4 } \\
\text { NDW }\end{array}$} & \multicolumn{5}{|l|}{$\mathrm{R} 2$} \\
\hline & & & NDW & SNC & TSNC & $\% \mathrm{NU}$ & TNU \\
\hline \multirow{3}{*}{ Passo Fundo } & Transgenic with glyphosate & 0.72 & 1.29 & 40.76 & 3651.44 & 69.64 & 2576.59 \\
\hline & Transgenic with conventional herbicide & 0.66 & 1.11 & 38.31 & 2443.37 & 71.42 & 1771.38 \\
\hline & $p$ & ns & ns & ns & & & \\
\hline \multirow[t]{3}{*}{ Ponta Grossa ${ }^{a}$} & Transgenic with glyphosate & 0.77 & 1.63 & 47.29 & 9683.20 & 81.87 & 7715.54 \\
\hline & Transgenic with conventional herbicide & 0.76 & 1.50 & 45.71 & 8597.17 & 78.60 & 6685.19 \\
\hline & $p$ & ns & ns & ns & ns & & ns \\
\hline \multirow[t]{3}{*}{ Londrina } & Transgenic with glyphosate & 0.28 & 0.83 & 43.70 & 5368.17 & 73.03 & 3932.75 \\
\hline & Transgenic with conventional herbicide & 0.24 & 0.73 & 42.50 & 4580.97 & 73.69 & 3357.67 \\
\hline & $p$ & ns & ns & ns & & ns & \\
\hline \multirow[t]{3}{*}{ Uberaba } & Transgenic with glyphosate & 1.62 & 2.61 & 44.51 & 5552.90 & 77.69 & 4357.11 \\
\hline & Transgenic with conventional herbicide & 1.56 & 2.76 & 44.88 & 4976.10 & 78.49 & 3925.13 \\
\hline & $p$ & ns & ns & ns & & & ns \\
\hline \multirow[t]{3}{*}{ Planaltina } & Transgenic with glyphosate & 1.58 & 2.21 & 47.97 & 5477.55 & 79.71 & 4407.38 \\
\hline & Transgenic with conventional herbicide & 1.47 & 2.09 & 47.33 & 4769.00 & 80.01 & 3853.33 \\
\hline & $p$ & ns & ns & ns & ns & ns & ns \\
\hline \multirow[t]{3}{*}{ Luiz Eduardo Magalhães } & Transgenic with glyphosate & 1.11 & 3.40 & 44.51 & 5391.56 & 83.08 & 4535.04 \\
\hline & Transgenic with conventional herbicide & 1.11 & 3.03 & 44.40 & 4608.63 & 79.58 & 3714.93 \\
\hline & $p$ & ns & ns & ns & ns & & \\
\hline
\end{tabular}

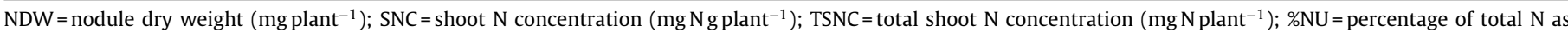
$\mathrm{N}$-ureide; TNU = total $\mathrm{N}$ as ureide- $\mathrm{N}$ ( $\mathrm{mg}$ ureide-N plant $\left.{ }^{-1}\right)$.

a This site was evaluated only during seasons 2004/2005 and 2005/2006.

* $p<0.05$.

${ }^{* *} p<0.005$

The comparison between the conventional soybean cropping management (conventional soybean with conventional herbicides) and the transgenic management (transgenic soybean with glyphosate) (Contrast 3, Table 4) showed that, in general, BNF was not affected by management system. Differences were observed only for \%NU in Passo Fundo, Londrina and Planaltina, where higher values were recorded with conventional soybean cropping management (relative increments of 3-5\%). At Uberaba and Luiz Eduardo Magalhães, no differences were observed in the BNF variables (Table 4).

Finally, it is worth mentioning that considering all experiments we found no correlation between symbiotic efficiency and soil chemical or physical properties (Table 1 ).

Table 4

Contrast analyses comparing transgenic soybean cultivars managed with glyphosate against non-transgenic cultivars managed with conventional herbicides (contrast 3 ) for individual parameters related to biological nitrogen fixation, across three cropping seasons.

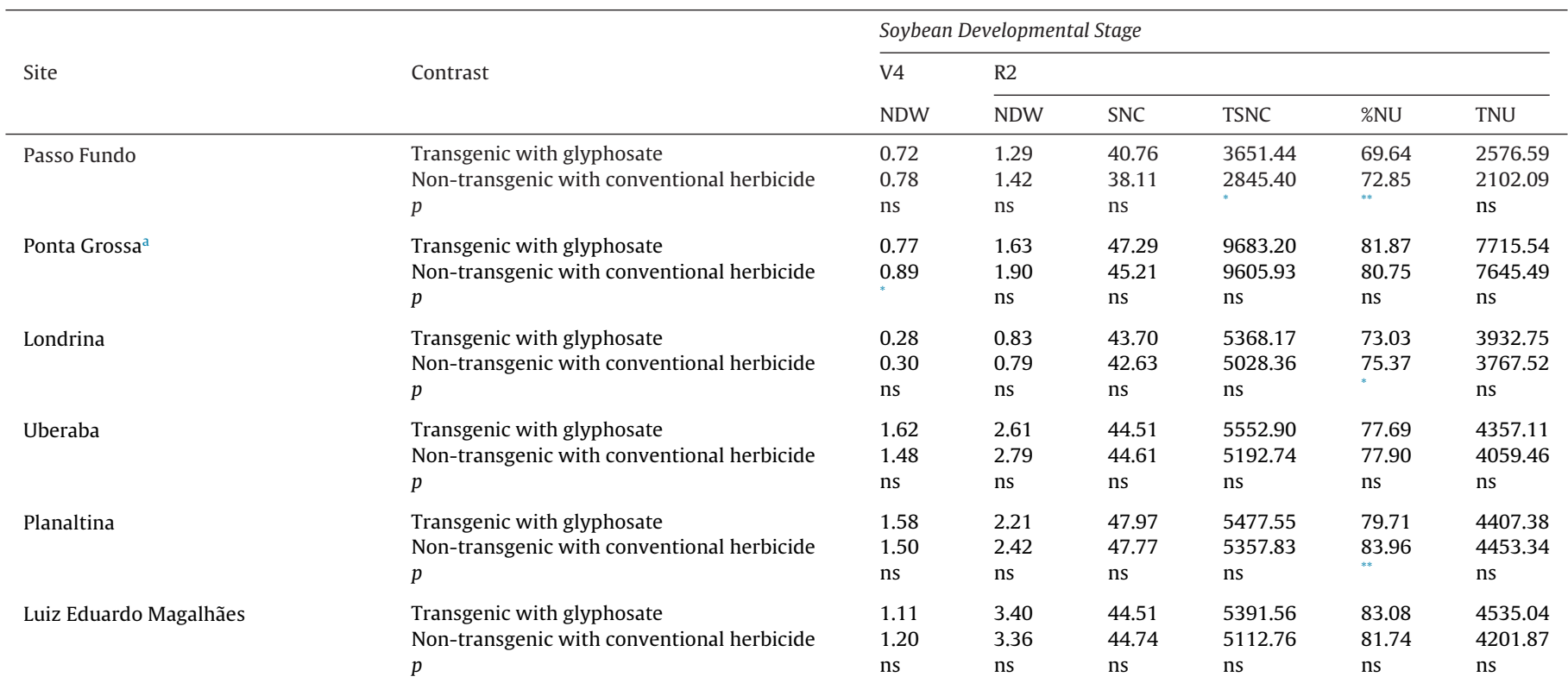

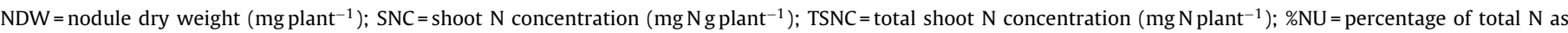
$\mathrm{N}$-ureide; $\mathrm{TNU}=$ total $\mathrm{N}$ as ureide- $\mathrm{N}$ ( $\mathrm{mg}$ ureide- $\mathrm{N}$ plant ${ }^{-1}$ ).

a This site was evaluated only during season 2004/2005 and 2005/2006.

${ }^{*} p<0.05$.

${ }^{* *} p<0.005$. 

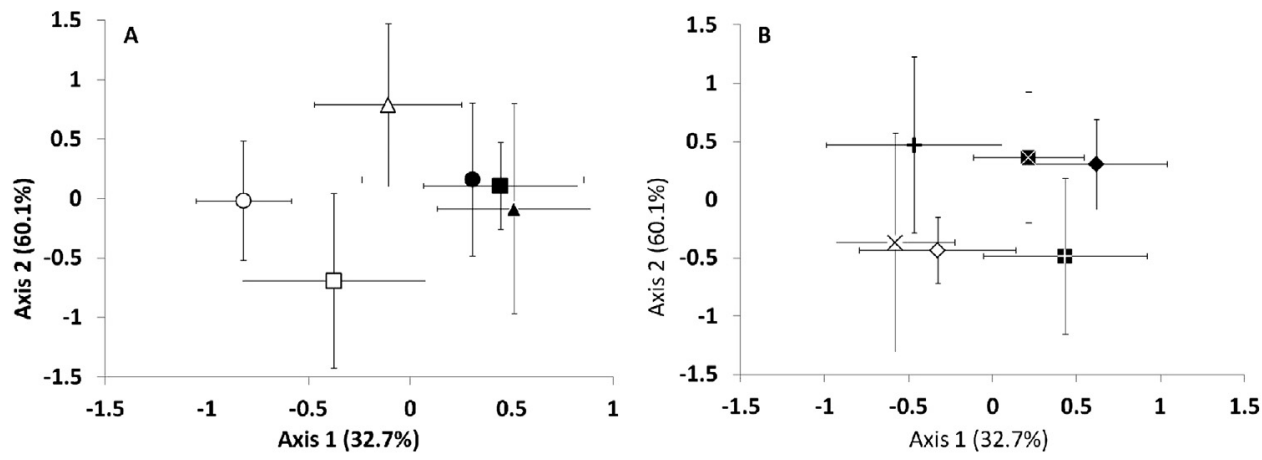

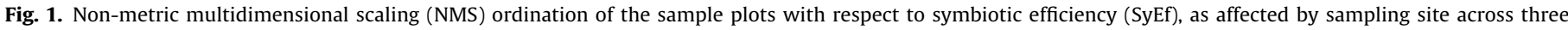

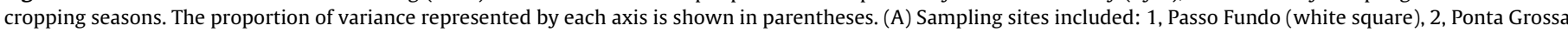

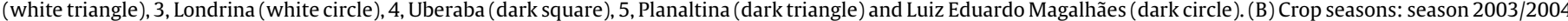

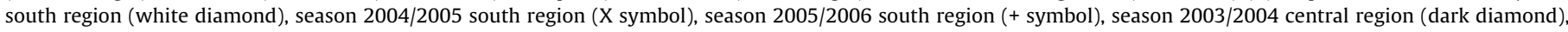
season 2004/2005 (dark X symbol), season 2005/2006 (dark + symbol). The horizontal and vertical bars indicate \pm 1 SD.

\subsection{Effects of the transgenic trait and glyphosate on symbiotic efficiency (SyEf) - multivariate analyses}

About $93 \%$ of the total data variability from the six variables in the symbiotic efficiency (SyEf) matrix was represented in a twodimension plot, according to the non-metric multidimensional scaling (NMS) ordination (Fig. 1). Axis 1 explained 33\% of the data variability and was positively correlated $(p<0.001)$ with all SyEf variables: NDW V4 $(r=0.89)$; NDW R2 $(r=0.73)$; \%NU R2 $(r=0.48)$; TNU R2 $(r=0.18)$; TSNC R2 $(r=0.13)$; and SNC R2 $(r=0.09)$.

According to NMS Axis 1 scores, the differences in SyEf were associated with location (south and central areas) and strongly and positively correlated with nodule dry weight at the V4 (NDW V4) and R2 (NDW R2) stages. Sites in the central region (Uberaba, Planaltina and Luis Eduardo Magalhães) were plotted in the right side, whereas the south-region sites (Passo Fundo, Londrina and Ponta Grossa) were plotted in the left side, along Axis 1 in Fig. 1A, showing that NDW increased from the south to the central sites. This division was confirmed by pairwise comparison using MRPP between all sites (Table 5 ).

NMS Axis 2 explained $60 \%$ of the data variability and it was significant correlated $(p<0.001)$ with five parameters: TNU R2 $(r=0.93)$; TSNC R2 $(r=0.92)$; SNC R2 $(r=0.56)$; NDW R2 $(r=0.42)$ and \%NU R2 $(r=0.34)$. Along this axis, SyEf changes were associated with seasonal differences in the central and south regions. In the south region, season 2005/2006 was plotted in the top and seasons

\section{Table 5}

Statistical significance ( $p$-value) and effect size ( $A$ value) of the sampling sites on symbiotic efficiency (SyEf) from six locations in Brazil across three cropping seasons, according with MRPP (multiresponse permutation procedure).

\begin{tabular}{|c|c|c|}
\hline Pair wise comparison by sites & $A$ value & $p$ \\
\hline Passo Fundo vs. Ponta Grossa & 0.19 & *** \\
\hline Passo Fundo vs. Londrina & 0.13 & *** \\
\hline Passo Fundo vs. Uberaba & 0.18 & *** \\
\hline Passo Fundo vs. Planaltina & 0.14 & *** \\
\hline Passo Fundo vs. LEM & 0.14 & ${ }^{* * *}$ \\
\hline Ponta Grossa vs. Londrina & 0.20 & *** \\
\hline Ponta Grossa vs. Uberaba & 0.16 & $* * *$ \\
\hline Ponta Grossa vs. Planaltina & 0.13 & *** \\
\hline Ponta Grossa vs. LEM & 0.13 & *** \\
\hline Londrina vs. Uberaba & 0.28 & *** \\
\hline Londrina vs. Planaltina & 0.26 & ${ }^{* * *}$ \\
\hline Londrina vs. LEM & 0.20 & ${ }^{* * *}$ \\
\hline Uberaba vs. Planaltina & 0.05 & ${ }^{* * *}$ \\
\hline Uberaba vs. LEM & 0.04 & *** \\
\hline Planaltina vs. LEM & 0.06 & *** \\
\hline
\end{tabular}

${ }^{* * *} p<0.001$; LEM = Luis Eduardo Magalhães; An A value of 0 means that the heterogeneity within groups are equal expectation by chance, whereas a 1 value means that all items are identical within groups.
2003/2004 and 2004/2005 were displayed in the bottom of Fig. $1 \mathrm{~B}$. In the central areas, opposite behavior was observed. Differences in SyEf were significant for all the pairwise comparisons between seasons ( $p<0.01$, MRPP), in the central and south regions.

The analysis of Contrast 1 by MRPP revealed differences between transgenic and non-transgenic treatments in terms of SyEf (Fig. 2A). However, when analyzing each site separately (Table 6), SyEf was not affected by the transgenic trait at Ponta Grossa and Uberaba. Fig. 2B displays the graphical representation of the comparison between transgenic and non-transgenic cultivars at Londrina, the site with the most significant difference between treatments, while Fig. 2C displays Uberaba with no significant differences (Table 6), respectively. At Londrina, non-transgenic treatments had higher values in four out of six parameters evaluated, with increases ranging from 5 to $17 \%$ (Table 2). However, even when differences in SyEf were observed between transgenic and non-transgenic treatments, as in Londrina (Fig. 2B), the effect was slight, as evidenced by its very low chance-corrected withingroup agreement ( $A$ " value $=0.011$ ) (Table 6), which describes the effect size that is independent of sample size. This " $A$ " value is close to zero, indicating that the heterogeneity of samples within groups (transgenic vs. non-trangenic sample groups) tends to that expected by chance, and, away from 1 , a condition in which no within-group variation would be observed. As pointed out by McCune and Grace (2002), for large datasets it is possible to obtain a significant $p$ value even for low values of " $A$ ".

The MRPP analysis for Contrast 2, which compares the effects of glyphosate and conventional herbicide on SyEf, indicated differences between the treatments (Table 6, Fig. 3A); however, the effect

Table 6

Statistical significance ( $p$-value) and effect size ( $A$ value) of the transgenic trait, type of herbicide and strategy of weed management on symbiotic efficiency (SyEf) tested by contrasts 1, 2 and 3, with MRPP (multiresponse permutation procedure).

\begin{tabular}{llll}
\hline \multirow{2}{*}{ Site } & \multicolumn{2}{l}{$l$ A values } & \\
\cline { 2 - 4 } & Contrast 1 & Contrast 2 & Contrast 3 \\
\hline Passo Fundo & $0.040 / 0.006$ & $0.005 / 0.023$ & $0.069 / 0.009$ \\
Ponta Grossa & $0.100 / 0.006$ & $0.251 / 0.003$ & $0.418 /-0.002$ \\
Londrina & $0.003 / 0.011$ & $0.073 / 0.008$ & $0.611 /-0.002$ \\
Uberaba & $0.716 /-0.002$ & $0.470 /-0.001$ & $0.473 /-0.001$ \\
Planaltina & $0.009 / 0.013$ & $0.484 /-0.002$ & $0.408 /-0.001$ \\
Luiz Eduardo Magalhães & $0.047 / 0.006$ & $0.179 / 0.004$ & $0.554 /-0.002$ \\
\hline
\end{tabular}

Contrast 1: compares treatments with transgenic and non-transgenic soybean cultivars.

Contrast 2: compares transgenic soybean cultivars managed with glyphosate and with conventional herbicides.

Contrast 3: compares transgenic soybean cultivars managed with glyphosate against non-transgenic cultivars managed with conventional herbicides. 

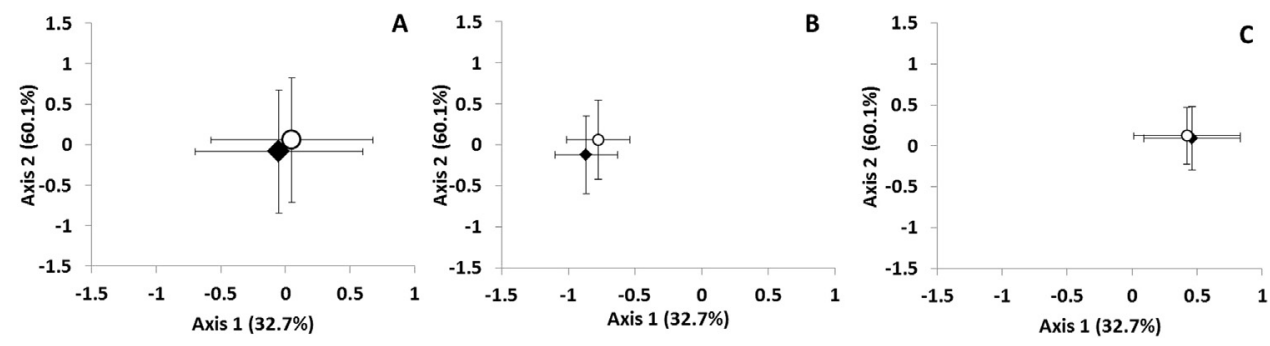

Fig. 2. NMS representation of the impact of transgenic and non-transgenic soybean cultivars (Contrast 1 ) on symbiotic efficiency considering all sites ( $p=0.000 ; A=0.003$ ) (A); Londrina $(p=0.003 ; A=0.011)$ (B) and Uberaba $(p=0.716 ; A=-0.002)(C)$ sites. These two sites presented the most contrasting conditions found by statistical analysis. Dark diamond = transgenic treatments; white circle = non-transgenic treatments. The horizontal and vertical bars indicate \pm 1 SD.
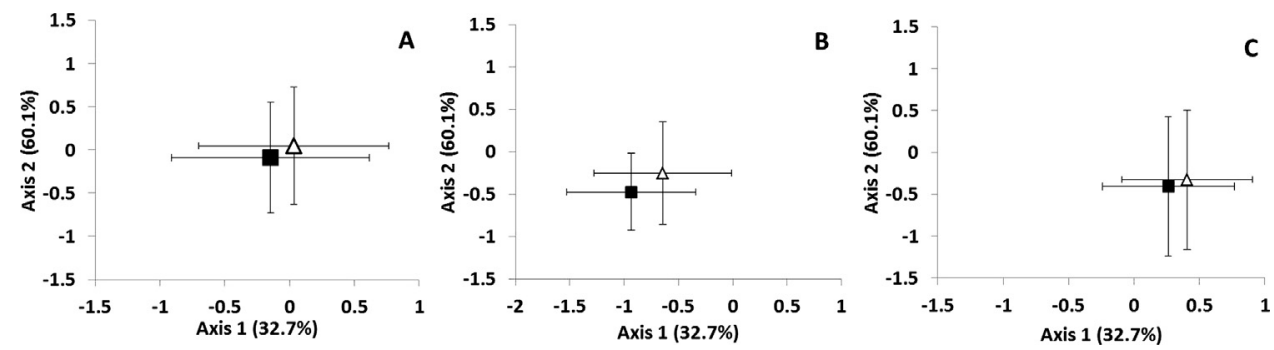

Fig. 3. NMS representation of the impact of treatments with transgenic soybean cultivars managed with glyphosate and with conventional herbicides (Contrast 2 ) on symbiotic efficiency considering all sites $(p=0.002 ; A=0.004)(\mathrm{A})$; Passo Fundo $(p=0.005 ; A=0.023)(\mathrm{B})$ and Planaltina $(p=0.484 ; A=-0.002)$ (C) sites. These two sites presented the most contrasting conditions found by statistical analysis. White triangle $=$ glyphosate treatments, Dark square $=$ conventional herbicides treatments. The horizontal and vertical bars indicate $\pm 1 \mathrm{SD}$.

was significant only at Passo Fundo (Table 6). Fig. 3B shows the NMS graphical representation of Contrast 2 at Passo Fundo, where between-treatment differences were most significant (glyphosate treatment had TNSC and TNU values $49 \%$ and $45 \%$ higher than those of its conventional counterpart, respectively), while Fig. $3 \mathrm{C}$ represents Planaltina, where no differences were detected. Again, although a significant $p$ value has been observed for this contrast at Passo Fundo, the size effect was very small (" $A$ " value $=0.02$ ).

No significant differences were observed between the two soybean cropping management practices-of transgenic soybean with glyphosate and non-transgenic soybean with conventional herbicides (Contrast 3)-on SyEf ( $p=0.155)$ (Table 6), in agreement with the results obtained in the univariate analysis.

As our dataset comprises different edaphoclimatic conditions, cropping seasons, cultivars and treatments, in order to measure the contribution of these distinct sources of variation on the variability of SyEf data in each of the tested contrasts, a "tree model" analysis was used, presented in Table 7. The variability found in the SyEf data can be explained mainly by the "site" factor (from 39 to $42 \%$ ), followed by "year" (from 29 to $30 \%$ ) and "cultivar" (from 6.9 to $7.9 \%$ ).

Table 7

Percentage of the data variability explained by the tree model for symbiotic efficiency (SyEf) in contrasts 1,2 and 3, as a function of site, year of sampling, cultivar and the tested contrast.

\begin{tabular}{lccc}
\hline Factor & Contrast 1 & Contrast 2 & Contrast 3 \\
\hline Site & 38.80 & 41.74 & 41.66 \\
Year & 30.20 & 29.40 & 31.06 \\
Cultivar & 7.20 & 6.86 & 7.85 \\
Contrast & 4.10 & 4.69 & 2.63 \\
Explained \% & 80.30 & 82.69 & 83.20 \\
\hline
\end{tabular}

Contrast 1 compares transgenic and non-transgenic soybean cultivars.

Contrast 2 compares transgenic soybean cultivars managed with glyphosate and with conventional herbicides.

Contrast 3 compares transgenic soybean cultivars managed with glyphosate and non-transgenic cultivars managed with conventional herbicides.
In contrast, herbicide type, transgenic trait and crop-management strategy, tested by the three contrasts, were associated with small fractions of the variability in the data (between $2.6 \%$ and $4.7 \%$ ).

\subsection{Effect of the transgenic trait and glyphosate on soybean yield}

For Contrast 1 , differently from what was observed for SyEf, soybean yield was not affected by the transgenic trait (Table 8). Only at Passo Fundo there were reductions in soybean yield (21\%) and TGN $(17 \%)$ in the treatments with transgenic soybean cultivars. However, it is noteworthy that at Passo Fundo, yield was evaluated only in the 2003/2004 season, during which crop growth was affected by a period of drought. Drought-related problems also occurred in the two subsequent growing seasons, resulting in loss of yield data for this site.

Except for Uberaba and Planaltina, where no differences were found between herbicide types (Contrast 2), the use of glyphosate instead of conventional herbicides resulted in higher grain yields (from 9 to 34\%) and TGN (from 7 to 33\%) (Table 9).

For Contrast 3, comparing the soybean crop-management practices (transgenic with glyphosate $\times$ non-transgenic with conventional herbicide), higher yields were obtained from the former at Ponta Grossa (11\%), Londrina (10\%), Luis Eduardo Magalhães (12\%) and Planaltina (12\%, in this case statistically non-significant) (Table 10).

\subsection{Correlation between symbiotic efficiency and soybean yield}

NMS Axis 1 and Axis 2, which represented about 33\% and 60\% of SyEf variation, respectively, were correlated $(p<0.001)$ both with soybean yield (Fig. 4A and C) and total grain N content (Fig. 4B and D). Axis 1 and Axis 2 clearly demonstrated that variations in SyEf were associated with region and cropping season within region, respectively (Fig. 1A and B). Our results show that variations in SyEf associated with region and cropping season are in agreement 

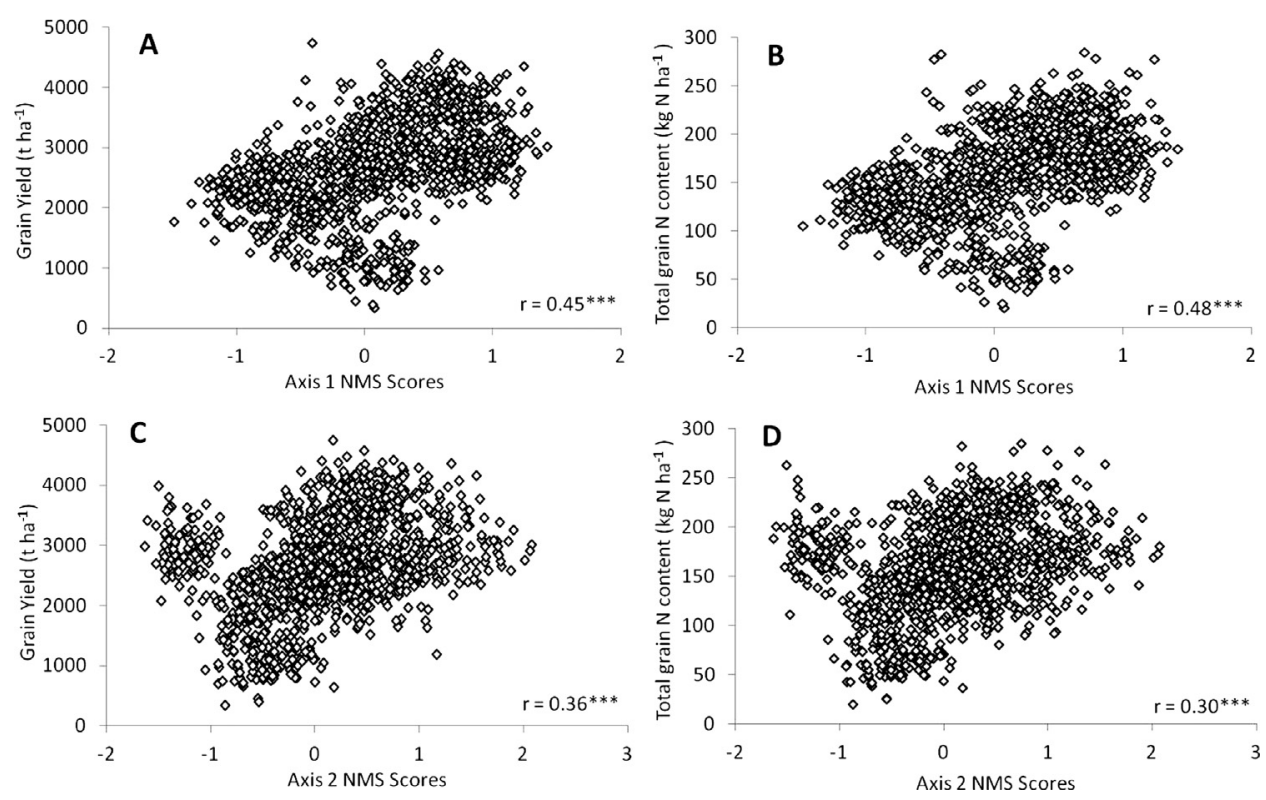

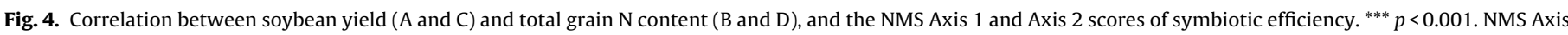
$1=32.7 \%$, Axis $2=60.1 \%$.

with the variations recorded for soybean grain yield and $\mathrm{N}$ content. Higher values of soybean yield were observed in the central area (Uberaba, Planaltina and Luis Eduardo Magalhães), in agreement with higher values of BNF parameters in these areas (Tables 2-4). Similarly, season 2005/2006 in the south-region areas and seasons $2003 / 2004$ and 2004/2005 in the central region areas presented higher soybean yields, as well as superiority in BNF parameters (data not shown).

\section{Table 8}

Contrast analyses, comparing treatments with transgenic and non-transgenic soybean cultivars (Contrast 1 ), for the soybean grain yield (SGY), the percentage of grain $\mathrm{N}(\% \mathrm{GN})$ and the total grain $\mathrm{N}$ content (TGN), across three cropping seasons.

\begin{tabular}{|c|c|c|c|c|}
\hline Site & Contrast & SGY & $\% \mathrm{GN}$ & TGN \\
\hline \multirow[t]{3}{*}{ Passo Fundo ${ }^{a}$} & Transgenic & 859 & 6.06 & 55.0 \\
\hline & Non-transgenic & 1094 & 6.11 & 66.6 \\
\hline & $P$ & & ns & \\
\hline \multirow[t]{3}{*}{ Ponta Grossa ${ }^{\mathrm{b}}$} & Transgenic & 2545 & 5.97 & 153.95 \\
\hline & Non-transgenic & 2512 & 5.97 & 150.50 \\
\hline & $P$ & ns & ns & ns \\
\hline \multirow[t]{3}{*}{ Londrina } & Transgenic & 2230 & 5.73 & 127.01 \\
\hline & Non-transgenic & 2249 & 5.79 & 129.51 \\
\hline & $P$ & ns & ns & ns \\
\hline \multirow[t]{3}{*}{ Uberaba } & Transgenic & 2957 & 5.94 & 175.72 \\
\hline & Non-transgenic & 3023 & 6.02 & 181.75 \\
\hline & $P$ & ns & ns & ns \\
\hline \multirow[t]{3}{*}{ Planaltina } & Transgenic & 3378 & 5.93 & 198.89 \\
\hline & Non-transgenic & 3442 & 5.89 & 201.43 \\
\hline & $P$ & ns & ns & ns \\
\hline \multirow[t]{3}{*}{ Luiz Eduardo Magalhães } & Transgenic & 2550 & 6.50 & 161.35 \\
\hline & Non-transgenic & 2572 & 6.50 & 163.52 \\
\hline & $P$ & ns & ns & ns \\
\hline
\end{tabular}

SGY $\left(\mathrm{kg} \mathrm{ha}^{-1}\right), \% \mathrm{GN}\left(\mathrm{g} \mathrm{kg}^{-1}\right), \mathrm{TGN}\left(\mathrm{kg} \mathrm{Nha}^{-1}\right)$.

"Significant at $p<0.05$.

a At the Passo Fundo site, due to drought problems in 2004/2005 and 2005/2006, only the season $2003 / 2004$ was considered for data analysis.

b At the Ponta Grossa site due to drought problems in the season 2003/2004, only seasons 2004/2005 and 2005/2006 were considered for data analysis. Also at the Ponta Grossa site cultivar V2 was excluded from contrast analysis, because of missing data.

Significant at $p<0.005$.

\section{Discussion}

Most of the attributes used to assess BNF in our study were significantly correlated to both axes of NMS analyses, and together were able to represent more than $90 \%$ of the original data variability, confirming the feasibility of using these parameters for environmental monitoring assessments. Indeed, Souza et al. (2008a,b), in a large field study on transgenic soybean at several sites in Brazil, concluded that NDW, TSNC and TNU can be part of a minimum set of parameters to evaluate possible effects on BNF arising from the adoption of new technologies with soybean crops.

Several studies have evaluated the effects of herbicide-resistant plants and glyphosate on soil microorganisms, including the symbiotic nitrogen-fixing bacteria (Zablotowicz and Reddy, 2004; Pline-Srnic, 2005; Cerdeira and Duke, 2006; Böhm and Rombaldi, 2010). The results varied according to the conditions of each study. For instance, Böhm and Rombaldi (2010) reported that the effects of RR soybean on soil microorganisms were dependent on soil type and crop management. However, the effects were almost always associated with the herbicide rather than with the transgenic trait. The same authors pointed out that most studies analyzed a limited number of variables and were usually conducted under greenhouse or in vitro conditions. They concluded that, overall, the transgenic trait does not affect BNF.

\subsection{Effects of the transgenic trait on symbiotic efficiency (SyEf)}

Reports in the literature show that a variety of transgenes did not affect symbiotic $\mathrm{N}_{2}$-fixing microorganisms; for example, Powell et al. (2009) found no differences in NN or NDW between conventional and RR transgenic soybean. Masoud et al. (1996) also showed no effect of the transgene on the Rhizobium-alfalfa interaction, and Suarez et al. (2003) observed that the transgenic trait did not harm the interaction between Lotus japonicus and Mesorhizobium loti. In addition, Boisson-Dernier et al. (2001) verified that Sinorhizobium meliloti successfully nodulated transgenic Medicago truncatula.

However, in our study, differences in parameters related to BNF between RR transgenic and nearly isogenic non-transgenic soybean cultivars were observed in five out of six sites evaluated. The harmful effects of the transgenic trait on BNF attributes may be due 
Table 9

Contrast analyses comparing transgenic soybean cultivars managed with glyphosate and with conventional herbicides (Contrast 2), for the soybean grain yield (SGY), the percentage of grain $\mathrm{N}(\% \mathrm{GN})$ and the total grain $\mathrm{N}$ content (TGN), across three cropping seasons.

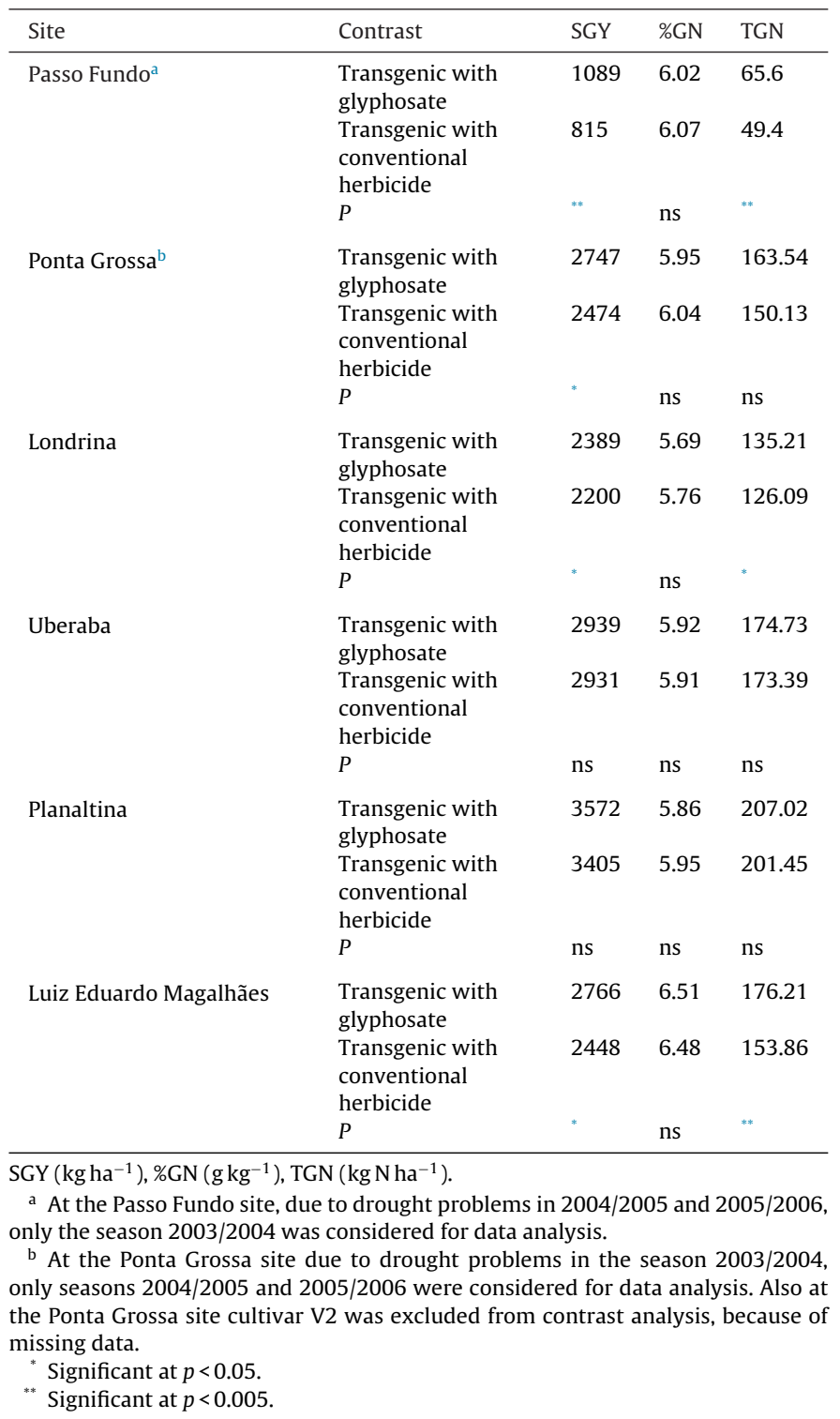

to changes in the root exudates and transgenic-plant physiology (Lynch et al., 2004; Kremer et al., 2005; Powell et al., 2007; GarciaVillalba et al., 2008; Zobiole et al., 2010; Moldes et al., 2012), which may impair growth of diazotrophic bacteria (Kremer and Means, 2009), and/or functioning of the symbiosis (Montero et al., 2001), resulting in lower NDW and smaller contributions of $\mathrm{N}$ to the soybean derived from BNF (Bohm et al., 2009). Altogether, these results demonstrate that the effects of transgenes on BNF must be seriously considered, as they may jeopardize the benefits from the symbiosis to soybean crops.

\subsection{Effect of glyphosate on symbiotic efficiency (SyEf)}

In general, there were higher values of BNF attributes under glyphosate application compared to the conventional herbicides. Although negative effects of glyphosate on Bradyrhizobium japonicum have been found (King et al., 2001), inhibition in the growth of Bradyrhizobium by glyphosate occurred at concentrations much
Table 10

Contrast analyses comparing transgenic soybean cultivars managed with glyphosate against non-transgenic cultivars managed with conventional herbcides (Contrast 3 ), for the soybean grain yield (SGY), the percentage of grain $\mathrm{N}$ (\%GN) and the total grain $\mathrm{N}$ content (TGN), across three cropping seasons.

\begin{tabular}{|c|c|c|c|c|}
\hline Site & Contrast & SGY & $\% G N$ & TGN \\
\hline \multirow[t]{3}{*}{ Passo Fundo ${ }^{\mathrm{a}}$} & $\begin{array}{l}\text { Transgenic with } \\
\text { glyphosate }\end{array}$ & 1089 & 6.02 & 65.6 \\
\hline & $\begin{array}{l}\text { Non-transgenic } \\
\text { with conventional } \\
\text { herbicide }\end{array}$ & 1067 & 6.17 & 65.6 \\
\hline & $P$ & ns & ${ }^{* *}$ & ns \\
\hline \multirow[t]{3}{*}{ Ponta Grossa ${ }^{b}$} & $\begin{array}{l}\text { Transgenic with } \\
\text { glyphosate }\end{array}$ & 2747 & 5.95 & 163.54 \\
\hline & $\begin{array}{l}\text { Non-transgenic } \\
\text { with conventional } \\
\text { herbicide }\end{array}$ & 2466 & 5.95 & 147.41 \\
\hline & $P$ & * & ns & 0.07 \\
\hline \multirow[t]{3}{*}{ Londrina } & $\begin{array}{l}\text { Transgenic with } \\
\text { glyphosate }\end{array}$ & 2389 & 5.69 & 135.21 \\
\hline & $\begin{array}{l}\text { Non-transgenic } \\
\text { with conventional } \\
\text { herbicide }\end{array}$ & 2178 & 5.76 & 124.55 \\
\hline & $P$ & ** & ns & * \\
\hline \multirow[t]{3}{*}{ Uberaba } & $\begin{array}{l}\text { Transgenic with } \\
\text { glyphosate }\end{array}$ & 2939 & 5.92 & 174.73 \\
\hline & $\begin{array}{l}\text { Non-transgenic } \\
\text { with conventional } \\
\text { herbicide }\end{array}$ & 2984 & 5.90 & 176.05 \\
\hline & $P$ & ns & ns & ns \\
\hline \multirow[t]{3}{*}{ Planaltina } & $\begin{array}{l}\text { Transgenic with } \\
\text { glyphosate }\end{array}$ & 3572 & 5.86 & 207.02 \\
\hline & $\begin{array}{l}\text { Non-transgenic } \\
\text { with conventional } \\
\text { herbicide }\end{array}$ & 3387 & 5.87 & 198.57 \\
\hline & $P$ & ns & ns & ns \\
\hline \multirow[t]{3}{*}{ Luiz Eduardo Magalhães } & $\begin{array}{l}\text { Transgenic with } \\
\text { glyphosate }\end{array}$ & 2766 & 6.51 & 176.21 \\
\hline & $\begin{array}{l}\text { Non-transgenic } \\
\text { with conventional } \\
\text { herbicide }\end{array}$ & 2462 & 6.45 & 154.68 \\
\hline & $P$ & * & ns & ** \\
\hline
\end{tabular}

SGY $\left(\mathrm{kg} \mathrm{ha}^{-1}\right)$, \%GN $\left(\mathrm{g} \mathrm{kg}^{-1}\right), \mathrm{TGN}\left(\mathrm{kg} \mathrm{N} \mathrm{ha}^{-1}\right)$.

a At the Passo Fundo site, due to drought problems in 2004/2005 and 2005/2006, only the season 2003/2004 was considered for data analysis.

b At the Ponta Grossa site due to drought problems in the season 2003/2004, only seasons 2004/2005 and 2005/2006 were considered for data analysis. Also at the Ponta Grossa site cultivar V2 was excluded from contrast analysis, because of missing data.

Significant at $p<0.05$

** Significant at $p<0.005$.

higher than those recommended for field application (Malty et al., 2006). Increases on BNF were also observed in transgenic soybean treated with glyphosate when compared to plants without the use of herbicides (Powell et al., 2009).

According to Cerdeira and Duke (2006) glyphosate is less toxic than other herbicides; the lethal dose for rats populations $\left(\mathrm{LD}_{50}\right)$ of glyphosate was $5600 \mathrm{mg} \mathrm{kg}^{-1}$, higher than for other herbicides. Procópio et al. (2004) found, under laboratory conditions, that glyphosate was less toxic for growth of Bradyrhizobium than the herbicides imazethapir and fomesafen. Drouin et al. (2010), screening the tolerance of 122 strains of four genera of Rhizobiaceae to seven herbicides, found that glyphosate inhibited the growth of only five strains; furthermore, glyphosate was less toxic than four other herbicides tested. In a field trial, Reis et al. (2010) observed that application of the herbicides fomesafen and fluazifop-p-butyl to soybean decreased nodule dry weight compared to a single application of glyphosate. In contrast, Böhm et al. (2009) found higher 
nodule dry matter under imazethapyr application compared to glyphosate applied once.

\subsection{Effect of the soybean crop management strategy on symbiotic efficiency (SyEf)}

The most useful comparison for farmers and policymakers is represented by the transgenic trait with glyphosate application in comparison with the non-trangenic nearly isogenic genotypes with conventional herbicides. Our results showed that soybean management practices had less influence on symbiotic efficiency, accounting for only $2.6 \%$ of the variability, whereas field site, cropping season and soybean cultivar accounted for almost $80 \%$ of variability. On the other hand, both univariate and multivariate analyses showed that soybean management did not significantly affect BNF traits.

According to Pline-Srnic (2005), cropping transgenic soybean with application of glyphosate use may affect interactions with symbiotic soil microorganisms, including rhizobia; however, these effects were minor in comparison to environmental factors, such as time and site of sampling (Lukow et al., 2000; Dunfield and Germida, 2004). Other studies on transgenic-plant effects on soil microorganisms showed impacts related to site, season and year, but unrelated to the transgenic trait (Lottmann et al., 1999; Heuer et al., 2002; Blackwood and Buyer, 2004). Also, plant development stage seems to have more importance than the transgenic event in terms of effects on soil microorganisms (Gyamfi et al., 2002; Souza et al., 2013). Even when transgenic plants affected the structure and functional diversity of microbial communities, changes were transient and absent from subsequent evaluations (Griffiths et al., 2000; Dunfield and Germida, 2003).

In contrast with our results-showing no effect of management type on BNF-Bohm et al. (2009) observed that transgenic soybean under glyphosate application presented lower NDW and N derived from BNF than non-transgenic soybean under imazethapyr application, and similar results were described by Kremer and Means (2009), who found lower NDW in RR soybean with glyphosate.

Another factor that must be considered is that, although negative effects of glyphosate on symbiotic $\mathrm{N}_{2}$-fixing bacteria have been reported in some studies (Zablotowicz and Reddy, 2007; Zobiole et al., 2011), under field conditions glyphosate can be degraded by rhizospheric microorganisms, that use it as a substrate (Haney et al., 2000). Liu et al. (1991) demonstrated in vitro that several members of Rhizobiaceae are capable of degrading and growing using glyphosate as a sole source of $P$, which may explain enhanced $\mathrm{N}_{2}$ fixation in RR soybean following glyphosate application (Powell et al., 2009).

When comparing the effects of the management method (Contrast 3), and not the isolated effect of the transgenic trait (Contrast 1 ) or of the herbicide (Contrast 2), we observed that glyphosate may favor the $\mathrm{N}_{2}$-fixing bacteria, as verified by both the univariate analysis and the MRPP analysis of Contrast 2, thus compensating the negative effects that the transgenic trait had on some BNF attributes (Contrast 1 ). In addition, promotion of BNF by the non-transgenic treatment (Contrast 1) may have decreased when considering the use of conventional herbicides, since these are more toxic to BNF than glyphosate (Procópio et al., 2004) (Contrast 2). Therefore, in an ultimate analysis, both types of soybean-cropping management methods were statistically similar to each other regarding their impacts on symbiotic efficiency (Contrast 3). However, it is noteworthy that the dose of glyphosate in our study was $2 \mathrm{Lha}^{-1}$, and that the effects of higher doses should be investigated. Weed resistance to glyphosate is increasingly reported, therefore, higher doses may become the norm.

\subsection{Effect of the transgenic trait and glyphosate on soybean yield}

Despite the effects of the transgenic trait (Contrast 1) on some of the BNF attributes, grain yield was not affected. One possibility is that soybean plants may compensate for any decrease of $\mathrm{N}$ derived from BNF by increasing absorption of soil $\mathrm{N}$, as observed by Bohm et al. (2009). This could lead to negative $\mathrm{N}$ balances and decreases in crop-system sustainability in the long term. These authors also did not find any negative effect of the transgenic event on soybean yield. On the other hand, if soil $\mathrm{N}$ becomes depleted, decreases in yield may be observed. This hypothesis deserves further studies.

In Passo Fundo, soybean yield was $21 \%$ lower $\left(235 \mathrm{~kg} \mathrm{ha}^{-1}\right)$ under transgenic cropping; however, it is important to emphasize that the data refer to only one growing season (2003/2004) which was affected by a period of drought that lowered yields. According to King et al. (2001), water stress can cause decreases in BNF and concomitant yield losses in RR soybean. For this reason it is prudent not to consider the transgenic trait effect in terms of yield in this site. It is also important to mention that no negative effects of the transgenic trait were observed in soybean yields in Luis Eduardo Magalhães, located in a sandy soil with limited $\mathrm{N}$ availability. According to Carpenter (2001), yield can vary year to year, as verified in Michigan (USA): in 1998, but not in 1999, RR soybean yield was lower than that of the conventional variety. In contrast, Elmore et al. (2001) observed that soybean yield was reduced by $5 \%\left(200 \mathrm{~kg} \mathrm{ha}^{-1}\right)$ in transgenic lines at four sites in Nebraska (USA), in two consecutive seasons.

There is no concrete evidence regarding grain-yield reductions by glyphosate under field conditions, when the herbicide is applied at the recommended rates (Zablotowicz and Reddy, 2004; PlineSrnic, 2005). Zablotowicz and Reddy (2007) in a field experiment over three years in Mississippi (USA) found no reduction in soybean yield by glyphosate when compared to the treatment without herbicide. Similarly, in a field study in Minas Gerais (Brazil), Reis et al. (2010) also did not observe differences in the yield of RR soybean with glyphosate or a mixture of fomesafen and fluazifop-p-butyl. The results obtained in the present study showed that treatments with glyphosate had increased grain yields compared to the treatments with conventional herbicides (Contrast 2). These data agree with Bohm et al. (2009) who obtained higher soybean yields with glyphosate application (between $27 \%$ and $37 \%$ ), when compared to imazethapyr application.

Carpenter (2010) evaluated 168 yield results from peerreviewed published studies on several genetically modified crops, and found that, in 124 cases, there were increased yields by the transgenic crops, 32 indicated no differences and only in 13 cases were yields reduced. Specifically for RR soybean, from 17 results, in 12 cases there were yield gains, in four no differences, and in just one case a decreased yield was recorded. These results corroborate our findings, where higher grain yields under transgenic soybean and glyphosate application were observed (Contrast 3 ). The highly significant and positive correlations between symbiotic efficiency and grain yield and TGN show the importance that BNF has to soybean-crop productivity, which is well documented in the literature (Alves et al., 2003; Hungria et al., 2006a,b; Rodriguez-Navarro et al., 2011).

\section{Concluding remarks}

The comparison of the pairs of non-transgenic and nearly isogenic transgenic soybean cultivars has shown that the transgenic trait negatively affected some BNF variables, but that over a threeyear period these effects had no significant impact on soybean grain yield. No consistent differences between glyphosate and conventional herbicide application were observed on BNF-associated variables. 
When compared to conventional soybean and conventional herbicides, weed-management strategy with RR soybean and glyphosate did not affect symbiotic efficiency, as measured by the assessment of several attributes related to BNF. In addition, at three sites, grain yields increased in the treatments with glyphosate and RR soybean across three cropping seasons.

\section{Acknowledgments}

Authors are thankful to the Embrapa' researchers Dr. Ana Claudia Barneshe de Oliveira, Dr. Neylson Eustáquio Arantes and Dr. Paulo Fernando Bertagnolli for help in the field experiments in Luiz Eduardo Magalhães, Uberaba and Passo Fundo, respectively, and to Dr. Carlos Arrabal Arias for helping in seed supply. Authors also thank to the field technical support of Rubson Natal Ribeiro Sibaldelli, to the field workers of the Microbiology team, and to the laboratory support of Rinaldo Benedito Conceição in all experiments. Finally, we thank to Dr. Allan R. J. Eaglesham for English correction and suggestions on the manuscript and Dr. Marco Antonio Nogueira for scientific suggestions. The project was partially financed by FINEP (Financiadora de Estudos e Projetos), and the research group is supported by $\mathrm{CNPq}$ (National Council for Scientific and Technological Development), Project Repensa (562008/20101). This manuscript was analyzed and approved for publication by the Editorial Board of Embrapa Soja as manuscript 183/2013. Authors either are fellows or received fellowships from CNPq.

\section{References}

Alves, B.J.R., Boddey, R.M., Urquiaga, S., 2003. The success of BNF in soybean in Brazil. Plant Soil 252, 1-9.

Blackwood, C., Buyer, J., 2004. Soil microbial communities associated with Bt and non-Bt corn in three soils. J. Environ. Qual. 33, 832-836.

Böhm, G.M.V., Rombaldi, C.V., 2010. Genetic transformation and the use glyphosate on soil microbial, biological nitrogen fixation, quality and safety of genetically modified soybean. Cienc. Rural 40, 213-221.

Bohm, G.M.V., Alves, B.J.R., Urquiaga, S., Boddey, R.M., Xavier, G.R., Hax, F., Rombaldi, C.V., 2009. Glyphosate- and imazethapyr-induced effects on yield, nodule mass and biological nitrogen fixation in field-grown glyphosate-resistant soybean. Soil Biol. Biochem. 41, 420-422.

Boisson-Dernier, A., Chabaud, M., Garcia, F., Becard, G., Rosenberg, C., Barker, D., 2001. Agrobacterium rhizogenes-transformed roots of Medicago truncatula for the study of nitrogen-fixing and endomycorrhizal symbiotic associations. Mol. Plant-Microbe Interact. 14, 695-700.

Breiman, L., Friedman, J.H., Olshen, R.A., Stone, C.G., 1984. Classification and Regression Tree. Wadsworth International Group, Belmont, CA, USA, 358 pp.

Carpenter, J.E., 2001. Comparing Roundup Ready and Conventional Soybean Yields: 1999. National Center for Food and Agricultural Policy, Washington, DC.

Carpenter, J.E., 2010. Peer-reviewed surveys indicate positive impact of commercialized GM crops. Nat. Biotechnol. 28, 319-321.

Carpenter, J.E., Gianessi, L.P., 2001. Agricultural biotechnology: Updated benefit estimates. National Center for Food and Agriculture Policy, Washington, DC, 46 pp.

Cerdeira, A., Duke, S., 2006. The current status and environmental impacts of glyphosate-resistant crops: a review. J. Environ. Qual. 35, 1633-1658.

De'ath, G., 2002. Multivariate regression trees: a new technique for modeling species-environment relationships. Ecology 83, 1105-1117.

De'ath, G., Fabricius, K., 2000. Classification and regression trees: a powerful yet simple technique for ecological data analysis. Ecology 81, 3178-3192.

Drouin, P., Sellami, M., Prevost, D., Fortin, J., Antoun, H., 2010. Tolerance to agricultural pesticides of strains belonging to four genera of Rhizobiaceae. J. Environ. Sci. Health B: Pestic. Contam. Agric. Wastes 45, 757-765.

Dunfield, K., Germida, J., 2003. Seasonal changes in the rhizosphere microbial communities associated with field-grown genetically modified canola (Brassica napus). Appl. Environ. Microbiol. 69, 7310-7318.

Dunfield, K., Germida, J., 2004. Impact of genetically modified crops on soil- and plant-associated microbial communities. J. Environ. Qual. 33, 806-815.

Dvoranen, E.C., Oliveira Jr., R.S., Constantin, J., Cavalieri, S.D., Blainski, E., 2008. Nodulação e crescimento de variedades de soja RR sob aplicação de glyphosate, fluazifopp-butyl e fomesafen. Planta Daninha 26, 619-625.

Elmore, R., Roeth, F., Nelson, L., Shapiro, C., Klein, R., Knezevic, S., Martin, A., 2001. Glyphosate-resistant soybean cultivar yields compared with sister lines. Agron. J. 93, 408-412

Fehr, W., Caviness, C., Burmood, D.T., Pennington, J.S., 1971. Stage of development descriptions for soybeans, Glycine max (L) Merrill. Crop Sci. 11, 929-931.

Fisher, R.S., Berry, A., Gaines, C.G., Jensen, R.A., 1986. Comparative action of glyphosate as a trigger of energy drain in eubacteria. J. Bacteriol. 168, 1147-1154.
Franz, J.E., Mao, M.K., Sikorski, J.A., 1997. Glyphosate: a unique global herbicide. American Chemical Society Monograph, vol. 189. American Chemical Society, Washington, DC

Garcia-Villalba, R., Leon, C., Dinelli, G., Segura-Carretero, A., Fernandez-Gutierrez, A., Garcia-Canas, V., Cifuentes, A., 2008. Comparative metabolomic study of transgenic versus conventional soybean using capillary electrophoresis-timeof-flight mass spectrometry. J. Chromatogr. A 1195, 164-173.

Gonzalez, A., Gonzalez-Murua, C., Royuela, M., 1996. Influence of imazethapyr on Rhizobium growth and its symbiosis with pea (Pisum sativum). Weed Sci. 44, 31-37.

Griffiths, B., Geoghegan, I., Robertson, W., 2000. Testing genetically engineered potato, producing the lectins GNA and Con A, on non-target soil organisms and processes. J. Appl. Ecol. 37, 159-170.

Gyamfi, S., Pfeifer, U., Stierschneider, M., Sessitsch, A., 2002. Effects of transgenic glufosinate-tolerant oilseed rape (Brassica napus) and the associated herbicide application on eubacterial and Pseudomonas communities in the rhizosphere. FEMS Microbiol. Ecol. 41, 181-190.

Haney, R., Senseman, S., Hons, F., Zuberer, D., 2000. Effect of glyphosate on soil microbial activity and biomass. Weed Sci. 48, 89-93.

Hernandez, A., Garcia-Plazaola, J.I., Becerril, J.M., 1999. Glyphosate effects on phenolic metabolism of nodulated soybean (Glycine max L. Merr.). J. Agric. Food Chem. 47, 2920-2925.

Herridge, D., Peoples, M., 1990. Ureide assay for measuring nitrogen-fixation by nodulated soybean calibrated by N-15 methods. Plant Physiol. 93, 495-503.

Heuer, H., Kroppenstedt, R., Lottmann, J., Berg, G., Smalla, K., 2002. Effects of T4 lysozyme release from transgenic potato roots on bacterial rhizosphere relative to communities are negligible natural factors. Appl. Environ. Microbiol. 68, 1325-1335.

Hungria, M., Campo, R.J., Mendes, I.C., Graham, P.H., 2006a. Contribution of biological nitrogen fixation to the $\mathrm{N}$ nutrition of grain crops in the tropics: the success of soybean (Glycine max L. Merr.) in South America. In: Singh, R.P., Shankar, N., Jaiwal, P.K. (Eds.), Nitrogen Nutrition and Sustainable Plant Productivity. Studium Press, LLC, Houston, TX, pp. 43-93.

Hungria, M., Franchini, J., Campo, R., Crispino, C., Moraes, J., Sibaldelli, R., Mendes, I., Arihara, J., 2006b. Nitrogen nutrition of soybean in Brazil: contributions of biological $\mathrm{N}_{2}$ fixation and $\mathrm{N}$ fertilizer to grain yield. Can. J. Plant Sci. 86, 927-939.

Hungria, M., Mendes, I.C., Mercante, F.M., 2013. A fixação biológica do nitrogênio como tecnologia de baixa emissão de carbono para as culturas do feijoeiro e da soja. Embrapa Soja, Londrina, Brazil. 22 pp. (Documentos, 337).

ISAAA (International Service of the Acquisition of Agri-Biotech Applications), 2012 Available at: http://www.isaaa.org/resources/publications (verified 21.09.12).

Jaworski, E.G., 1972. Mode of action of N-phosphonomethylglycine: inhibition of aromatic amino acid biosynthesis. J. Agric. Food Chem. 20, 1195-1198.

Johnson, B.J., 1971. Effect of herbicide combinations on weeds and soybeans. Weed Sci. 19, 740-742

King, C., Purcell, L., Vories, E., 2001. Plant growth and nitrogenase activity of glyphosate-tolerant soybean in response to foliar glyphosate applications. Agron. J. 93, 179-186.

Kremer, R., Means, N., 2009. Glyphosate and glyphosate-resistant crop interactions with rhizosphere microorganisms. Eur. J. Agron. 31, 153-161.

Kremer, R., Means, N., Kim, S., 2005. Glyphosate affects soybean root exudation and rhizosphere micro-organisms. Int. J. Environ. Anal. Chem. 85, 1165-1174.

Liu, C., Mclean, P., Sookdeo, C., Cannon, F., 1991. Degradation of the herbicide glyphosate by members of the family rhizobiaceae. Appl. Environ. Microbiol. 57, 1799-1804.

Lottmann, J., Heuer, H., Smalla, K., Berg, G., 1999. Influence of transgenic T4lysozyme-producing potato plants on potentially beneficial plant-associated bacteria. FEMS Microbiol. Ecol. 29, 365-377.

Lukow, T., Dunfield, P., Liesack, W., 2000. Use of the T-RFLP technique to assess spatial and temporal changes in the bacterial community structure within an agricultural soil planted with transgenic and non-transgenic potato plants. FEMS Microbiol. Ecol. 32, 241-247.

Lynch, J., Benedetti, A., Insam, H., Nuti, M., Smalla, K., Torsvik, V., Nannipieri, P., 2004. Microbial diversity in soil: ecological theories, the contribution of molecular techniques and the impact of transgenic plants and transgenic microorganisms. Biol. Fertil. Soils 40, 363-385.

Malty, J., Siqueira, J., Moreira, F., 2006. Effects of glyphosate on soybean symbiotic microorganisms, in culture media and in greenhouse. Pesq. Agropec. Bras. 41 285-291.

Masoud, S.A., Zhu, Q., Lamb, C., Dixon, R.A., 1996. Constitutive expression of an inducible beta-1,3-glucanase in alfalfa reduces disease severity caused by the oomycete pathogen Phytophthora megasperma f sp. medicaginis, but does not reduce disease severity of chitin-containing fungi. Transgenic Res. 5 , 313-323.

Mathsoft, 1999. S-Plus 2000 User’s Guide. Mathsoft Data Analysis Products Division, Seattle, WA, USA

McCune, B., Grace, J.B., 2002. Analysis of Ecological Communities. MjM Software Design, Gleneden Beach, OR, USA.

McCune, B., Mefford, M.J., 2011. PC-ORD. Multivariate Analysis of Ecological Data. Version 6.0. MjM Software, Gleneden Beach, OR, USA

Mielke, P.W., Berry, K.J., 2000. Permutation Methods: A Distance Function Approach. Springer-Verlag, NY, USA, 352 pp.

Moldes, C., Camina, J., Medici, L., Tsai, S., Azevedo, R., 2012. Physiological effects of glyphosate over amino acid profile in conventional and transgenic soybean (Glycine max). Pest. Biochem. Physiol. 102, 134-141. 
Montero, F.A., Filippi, K.M., Sagardoy, M.A., 2001. Nodulación y nutrición nitrogenada en sojas convencionales y resistentes a glifosato inoculadas con Bradyrhizobium japonicum. Cienc. Suelo 19, 159-162.

Moorman, T.B., Becerril, J.M., Lydon, J., Duke, S.O., 1992. Production of hydroxybenzoic acids by Bradyrhizobium japonicum strains after treatment with glyphosate. J. Agric. Food Chem. 40, 289-293.

Padgette, S.R., Kolacz, K.N., Delannay, X., Re, D.B., La Valee, B.J., Tinius, C.N., Rhoades, W.K., Otero, Y.L., Barry, G.F., Eicholtz, D.A., Peschie, V.M., Nida, D.L., Taylor, N.B., Kishore, G.M., 1995. Development, identification, and characterization of a glyphosate-tolerant soybean line. Crop Sci. 35, 1451-1461.

Pline-Srnic, W., 2005. Technical performance of some commercial glyphosateresistant crops. Pest Manag. Sci. 61, 225-234.

Powell, J., Campbell, R., Dunfield, K., Gulden, R., Hart, M., Levy-Booth, D., Klironomos, J., Pauls, K., Swanton, C., Trevors, J., Antunes, P., 2009. Effect of glyphosate on the tripartite symbiosis formed by Glomus intraradices, Bradyrhizobium japonicum, and genetically modified soybean. Appl. Soil Ecol. 41, 128-136.

Powell, J., Gulden, R., Hart, M., Campbell, R., Levy-Booth, D., Dunfield, K., Pauls, K., Swanton, C., Trevors, J., Klironomos, J., 2007. Mycorrhizal and rhizobial colonization of genetically modified and conventional soybeans. Appl. Environ. Microbiol. 73, 4365-4367.

Procópio, S.O., Santos, J.B., Jacques, R.J.S., Kasuya, M.C.M., Silva, A.A., Werlang, R.C. 2004. Crescimento de estirpes de Bradyrhizobium sob influência dos herbicidas glyphosate potássico, fomesafen, imazethapyr e carfentrazone-ethyl. Rev. Ceres 51, 179-188.

Reddy, K.N., Zablotowicz, R.M., 2003. Glyphosate-resistant soybean response to various salts of glyphosate and glyphosate accumulation in soybean nodules. Weed Sci. 51, 496-502.

Reddy, K.N., Hoagland, R.E., Zablotowicz, R.M., 2000. Effect of glyphosate on growth chrolophyll and nodulation in glyphosate-resistant and susceptible soyban (Glycine max) varieties. J. New Seeds 2, 37-52.

Reis, M., Silva, A., Pereira, J., Freitas, M., Costa, M., Silva, M., Santos, E., Franca, A., Ferreira, G., 2010. Impact of glyphosate associated with endosulphan and tebuconazole on the endosymbiotic microorganisms of the soybean. Planta Daninha $28,113-121$.
Rodriguez-Navarro, D.N., Oliver, I.M., Contreras, M.A., Ruiz-Sainz, J.E., 2011. Soybean interactions with soil microbes, agronomical and molecular aspects. Agron. Sustain. Dev. 31, 173-190.

SAS Institute, 1999. Proprietary of Software, Version 8, 6th ed. SAS Institute, Cary, NC, USA.

Sokal, R., 1979. Testing statistical significance of geographic-variation patterns. Syst. Zool. 28, 227-232.

Souza, R.A., Babujia, L.C., Silva, A.P., Guimarães, M.F., Arias, C.A., Hungria, M., 2013 Impact of the ahas transgene and of herbicides associated with the soybean crop on soil microbial community. Transgenic Res. (online).

Souza, R.A., Hungria, M., Franchini, J.C., Chueire, L.M.O., Barcellos, F.G., Campo, R.J. 2008a. Quantitative and qualitative evaluations of soil microbes and biological nitrogen fixation in soybean. Pesq. Agropec. Bras. 43, 71-82.

Souza, R.A., Hungria, M., Franchini, J.C., Maciel, C.D., Campo, R.J., Zaia, D., 2008b. Minimal set of parameters for evaluation soil microbiota and biological nitrogen fixation in soybean. Pesq. Agropec. Bras. 43, 83-91.

Suarez, R., Marquez, J., Shishkova, S., Hernandez, G., 2003. Overexpression of alfalfa cytosolic glutamine synthetase in nodules and flowers of transgenic Lotus japonicus plants. Physiol. Plant 117, 326-336.

Zablotowicz, R., Reddy, K., 2004. Impact of glyphosate on the Bradyrhizobium japonicum symbiosis with glyphosate-resistant transgenic soybean: a minireview. J Environ. Qual. 33, 825-831.

Zablotowicz, R., Reddy, K., 2007. Nitrogenase activity, nitrogen content, and yield responses to glyphosate in glyphosate-resistant soybean. Crop Prot. 26, 370-376.

Zobiole, L., Kremer, R., Oliveira, R., Constantin, J., 2011. Glyphosate affects chlorophyll, nodulation and nutrient accumulation of second generation glyphosate-resistant soybean (Glycine $\max$ L.). Pest. Biochem. Physiol. 99, 53-60.

Zobiole, L., Oliveira, R., Kremer, R., Constantin, J., Yamada, T., Castro, C., Oliveira F., Oliveira, A., 2010. Effect of glyphosate on symbiotic N-2 fixation and nickel concentration in glyphosate-resistant soybeans. Appl. Soil Ecol. 44, 176-180. 